\title{
Hydraulic Conductivity of Quarry Dust with Sandy Soils
}

\author{
P. Dayakar, K. Venkat Raman, R.Venkatakrishnaiah
}

\begin{abstract}
Water driven conductivity of soil is a significant property in Geotechnical Engineering, because of the way that a large number of the issues related with the plan and development of structures require the assurance of porousness of the dirt ( e.g., dewatering of unearthed locales, leakage through dams, and so forth.). Additionally the requirement for the assessment of the water driven conductivity of fine grained soils utilized as covering material for the regulation of squanders has created a lot of enthusiasm during the previous decade. An endeavor is made in this paper to ponder the impact of compaction on water powered conductivity of sandy soils through consistent head penetrability test in the research center. In this examination the impacts of three degrees of compaction on the water powered properties of two sandy soils and one quarry dust is assessed. Pressure driven conductivities are essentially diminished by the most noteworthy compaction level for every one of the examples. The outcomes show that dirt compaction could unequivocally impact, in various ways, the pressure driven properties of the dirts.
\end{abstract}

\section{Keywords penetrability \\ Geotechnical Engineering, conductivity,}

\section{INTRODUCTION}

Pressure driven conductivity of soils is a significant parameter in numerous seaward geotechnical studies and water system designing water dispersion frameworks, leakage misfortunes, surface and subsurface seepage frameworks, determination of harvests.[1]-[5]

Paola and Sathish kumar (2009) have presumed that the water powered conductivity and the coefficient of union of sands with $25 \%$ sediment content are roughly two sets of size littler than those of clean sands. The coefficient of volume compressibility of the sand-sediment blends is influenced in a lesser degree by void proportion, residue content, and limiting pressure. Porousness of compacted fine-grained soils is resolved routinely in the research facility utilizing unbending divider permeameters (Daniel 1981; Daniel et al. 1985). The

Revised Manuscript Received on October 22, 2019.

P. Dayakar, Associate Professor, Department Of Civil Engineering,,Bharath Institution Of Higher Education And Research,TamilNadu, India Email: dayakarpitti@yahoo.co.in

K. Venkat Raman Assistant Professor,,Department Of Civil Engineering,,Bharath Institution Of Higher Education And Research,TamilNadu, India E.Mail: venkatraman.civil@bharathuniv.ac.in

R.Venkatakrishnaiah Associate Professor ,Department Of Civil Engineering,,Bharath Institution Of Higher Education And Research,TamilNadu, India E.Mail venkatapec@gmail.com test normally is performed on the segment of the dirt that passes the No. 4 (4.75-mm) sifter.

Table 1 Properties of soil samples

\begin{tabular}{|c|c|c|c|}
\hline Description & $\begin{array}{c}\text { Fine Sand } \\
\text { (FS) }\end{array}$ & $\begin{array}{c}\text { Coarse Sand } \\
\text { (CS) }\end{array}$ & $\begin{array}{c}\text { Quarry Dust } \\
\text { (QD) }\end{array}$ \\
\hline Specific Gravity & 2.67 & 2.60 & 2.76 \\
\hline D10 & 0.099 & 0.73 & 0.1 \\
\hline D15 & 0.18 & 0.93 & 0.2 \\
\hline D30 & 0.24 & 1.05 & 0.4 \\
\hline D60 & 0.36 & 1.1 & 1.8 \\
\hline $\mathrm{Cc}$ & 1.6 & 1.767 & 0.88 \\
\hline $\mathrm{Cu}$ & 3.6 & 1.833 & 18 \\
\hline$x d \max$ & 1.84 & 1.78 & 2.26 \\
\hline OMC & 14.29 & 7.95 & 6.67 \\
\hline 8 . & 0.71 & 0.69 & 0.51 \\
\hline $\sin$ & 0.52 & 0.54 & 0.3 \\
\hline $8 x$ & 0.615 & 0.615 & 0.405 \\
\hline Classification & SW & SP & SP \\
\hline
\end{tabular}

\section{METHODOLOGY}

By knowing the amount, Q of water estimated, length, L of example, cross-sectional region, An of the example, time, $t$ required for the amount of water, $Q$ to be released, and head, $h$, the pressure driven conductivity can be determined:

$$
K=\frac{Q L}{A h t}
$$

To lead the arrangement of water driven conductivity test by consistent head technique, test arrangement as appeared in fig 2 is created. Table 2 outfits the elements of the acrylic chamber, which is utilized as parameter in this investigation. Care is taken to gauge the release and time as precisely as could be expected under the circumstances.[6]-[10]

Table 2 Details of the experimental setup

\begin{tabular}{|l|c|}
\hline \multicolumn{1}{|c|}{ Description } & Value \\
\hline Diameter of acrylic cylinder, $\mathrm{cm}$ & 19 \\
\hline Height of the acrylic cylinder L, cm & 26 \\
\hline Area of Specimen $\mathrm{A}, \mathrm{cm}^{2}$ & 283.39 \\
\hline Average flow Q, $\mathrm{cm}^{3} / \mathrm{sec}$ & 50 \\
\hline Constant Hydraulic head $\mathrm{h}, \mathrm{cm}$ & 37.5 \\
\hline
\end{tabular}




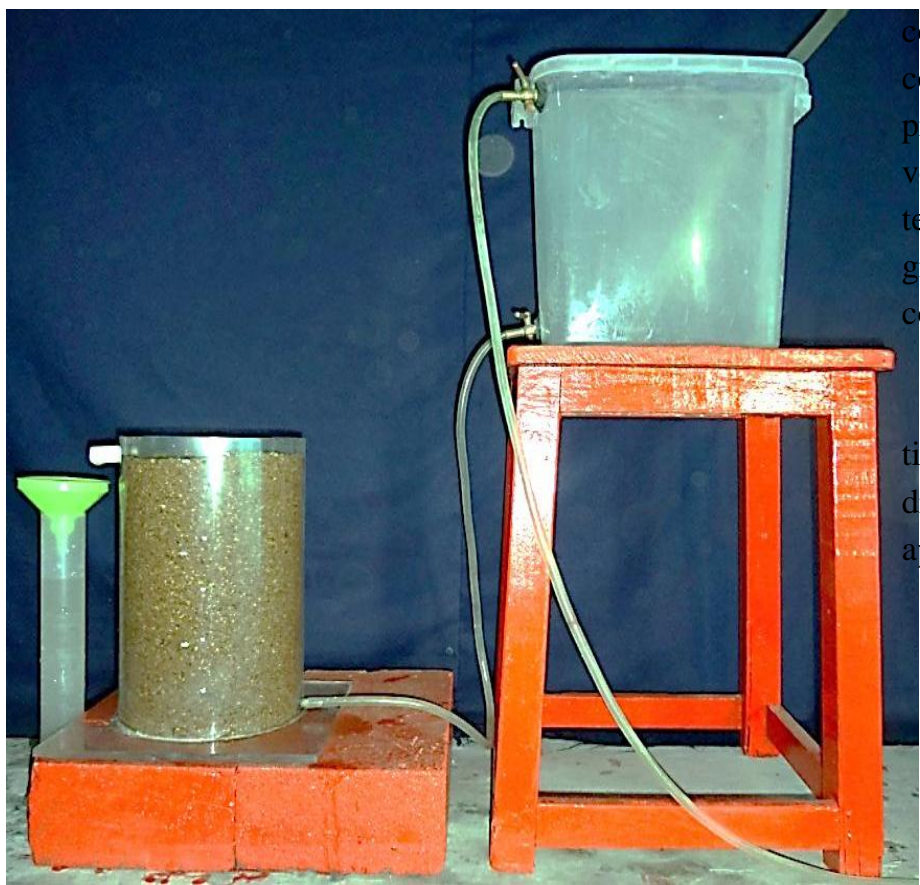

Fig 2 Hydraulic Conductivity typical test setup

Table 3 Notation Followed

\begin{tabular}{|l|c|c|}
\hline \multicolumn{1}{|c|}{ Description } & Notations & $\begin{array}{c}\text { Void } \\
\text { Ratio }\end{array}$ \\
\hline Fine Sand Loose State & FSLS & 0.71 \\
\hline Fine Sand MediumDense & FSMD & 0.615 \\
\hline Fine Sand Dense State & FSDS & 0.52 \\
\hline Coarse Sand Loose State & CSLS & 0.69 \\
\hline Coarse Sand Medium Dense & CSMD & 0.615 \\
\hline Coarse Sand Dense State & CSDS & 0.54 \\
\hline Quarry Dust Loose State & QDLS & 0.51 \\
\hline Quarry Dust MediumDense & QDMD & 0.405 \\
\hline Quarry Dust Dense State & QDDS & 0.3 \\
\hline
\end{tabular}

The water powered conductivity of fine sand in the free state is dictated by filling the fine sand in the barrel shaped compartment without compaction. The dry thickness in this state is seen as $1.56 \mathrm{~g} / \mathrm{cc}$ and the relating void proportion is 0.71 . The assurance of pressure driven conductivity of fine sand in the thick state is gotten by filling the fine sand in the acrylic tank by compacting it for each $5 \mathrm{~cm}$ filled to diminish the void proportion of the example. [21]-[25]

The thick condition of the fine sand is landed by compacting the layers filled in $5 \mathrm{~cm}$ with a wooden hammer for 30 blows each layer. The dry thickness in this state is seen as $1.75 \mathrm{gm} / \mathrm{cc}$ and the relating void proportion is 0.52 . A similar technique is followed in the assurance of pressure driven conductivity of coarse sand in the free state. The dry thickness in this state is seen as $1.53 \mathrm{~g} / \mathrm{cc}$ and the comparing void proportion is 0.54 . To decide the water driven onductivity of coarse sand in the medium thick express the oarse sand is filled in the acrylic tank to have a normal void roportion of the coarse sand which is landed by deciding the oid proportion in the free state and thick state. A similar chnique is followed in the quarry dust too. This obviously ives the impact of compaction on the water powered onductivity of the dirt examples. [11]-[16]

A connection between water driven conductivity and me taken to arrive at a consistent estimation of pressure riven conductivity for the fine sand in the free state is ppeared in fig 3.a and $b$
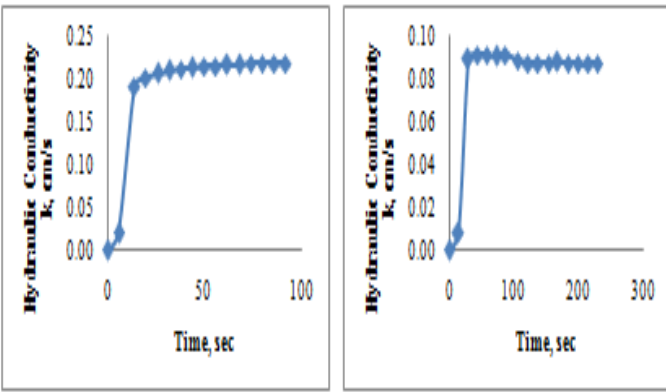

Fig 3.a Relationship between Hydraulic Conductivity and Time for Fine Sand - Loose Medium Dense state

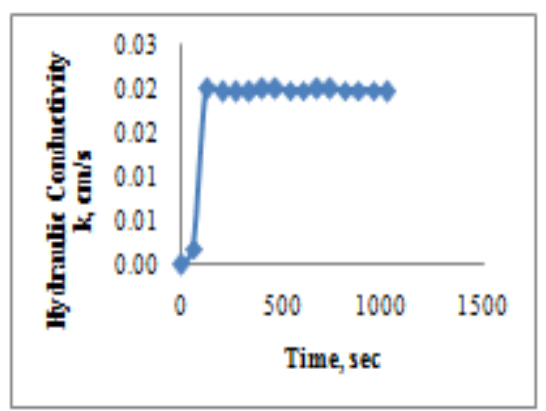

Fig 3.b Relationship between Hydraulic Conductivity and Time for Fine Sand -Dense state
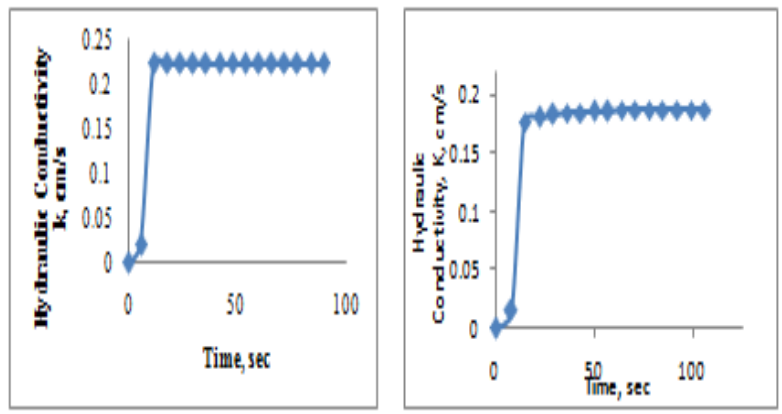

Fig 4. Relationship between Hydraulic Conductivity and Time for Coarse Sand - Loose Medium Dense and Dense state. 

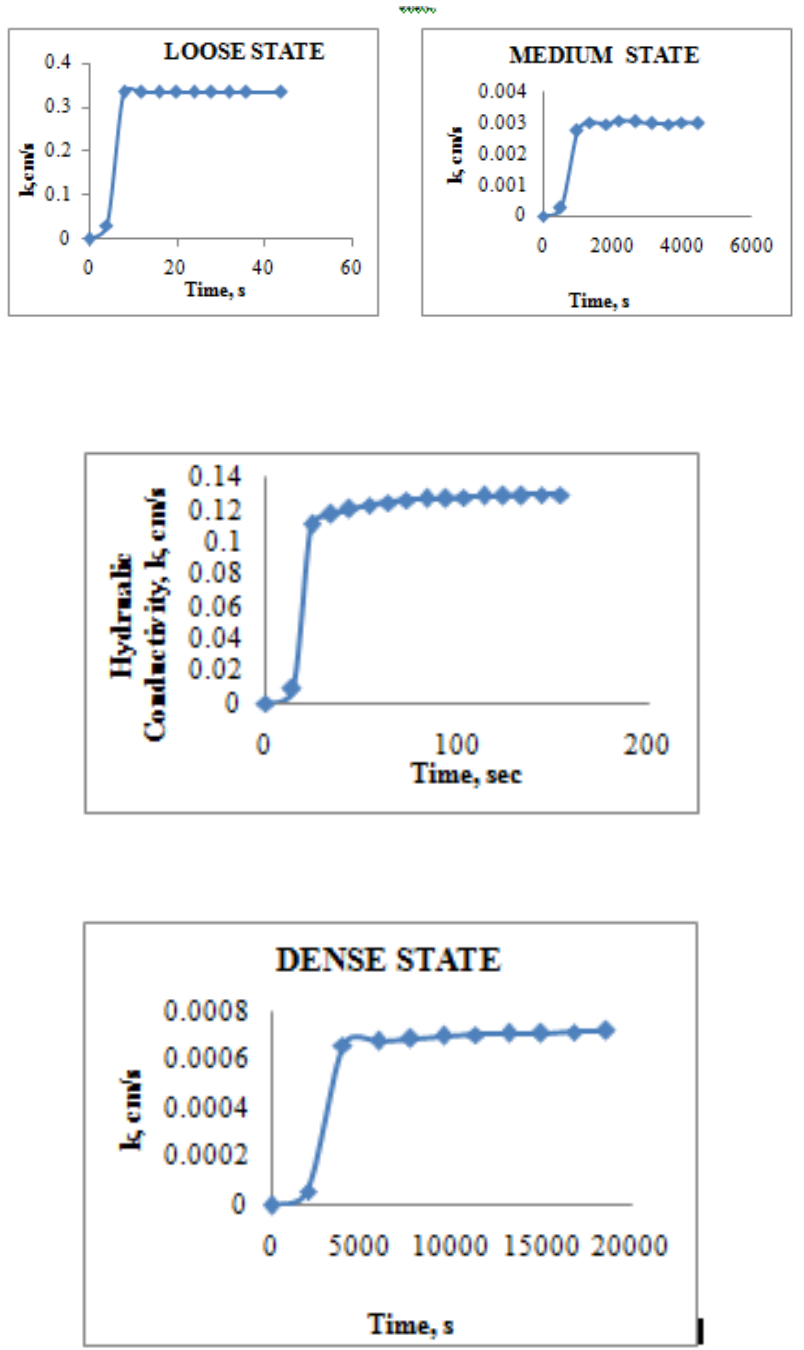

Fig 5. Relationship between Hydraulic Conductivity and Time for Quarry Dust - Loose Medium Dense and Dense state

\section{RESULT AND DISCUSSION}

From the trial examination of deciding water driven conductivity for different conditions of various soil tests, a correlation is made with the accessible observational relationship to decide the pressure driven conductivity. Table 4 shows the examination of water driven conductivity controlled by exact relationship to be specific Allen Hazen's condition and Sherard's condition alongside the test esteems. Table 4 shows the correlation of pressure driven conductivity of three diverse soil tests in three distinct states in particular free, medium thick and thick state. From the table, it very well may be comprehended that for a dirt free state gives higher water powered conductivity when contrast with thick state.[26]-34]

Table 4 Comparison of empirical formula \& experimental value for all the soil samples

\begin{tabular}{|c|c|c|c|c|}
\hline Soil & State & $\begin{array}{l}\text { Experimental } \\
\text { value } \mathrm{k}, \mathrm{cm} / \mathrm{s}\end{array}$ & $\begin{array}{c}\text { Allen Hazen's } \\
\text { Equation } \\
\text { k, cm/s } \\
\end{array}$ & $\begin{array}{c}\text { Sherard's Equation } \\
\text { k, cm/s }\end{array}$ \\
\hline Equation & & $\mathrm{k}=\mathrm{QL} / \mathrm{Aht}$ & $\mathrm{k}=\mathrm{C}(\mathrm{D} 10)^{2}$ & $\mathrm{k}=0.35(\mathrm{D} 15)^{2}$ \\
\hline Fine Sand & Loose & 0.1858 & \multirow{3}{*}{0.0225} & \multirow{3}{*}{0.011} \\
\hline Fine Sand & Medium & 0.0776 & & \\
\hline Fine Sand & Dense & 0.0173 & & \\
\hline Coarse Sand & Loose & 0.1957 & \multirow{3}{*}{0.5329} & \multirow{3}{*}{0.5} \\
\hline Coarse Sand & Medium & 0.1638 & & \\
\hline Coarse Sand & Dense & 0.1101 & & \\
\hline Quarry Dust & Loose & 0.2755 & \multirow{3}{*}{0.01} & \multirow{3}{*}{0.014} \\
\hline QuarryDust & Medium & 0.0024 & & \\
\hline QuarryDust & Dense & 0.0005 & & \\
\hline
\end{tabular}

A graphical representation of the relationship with void ratio and the hydraulic conductivity is also made and the same is shown in the fig 6.for all the three samples namely fine sand, coarse sand and quarry dust.
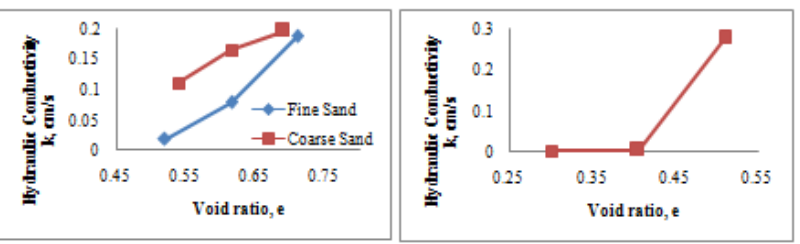

Fig 6 Relationship between void ratio and Hydraulic Conductivity of fine sand, coarse sand and quarry dust

\section{CONCLUSION}

In case of fine sand there is an abatement of $90 \%$ and $58 \%$ weight driven conductivity when thick state and the medium thick state is differentiated and free state separately. In case of coarse sand there is a diminishing of $43 \%$ and $16 \%$ water driven conductivity when thick state and the medium thick state is differentiated and free state independently. In case of quarry dust there is a diminishing of $99 \%$ and $99 \%$ weight driven conductivity when thick state and the medium thick state is differentiated and free state independently.

\section{REFERENCES}

1. Iyappan L., Dayakar P., Identification of landslide prone zone for coonoortalukusing spatial technology, International Journal of Applied Engineering Research,V-9,I-22,PP-5724-5732,Y-2014.

2. Kumar J., Sathish Kumar K., Dayakar P.,Effect of microsilica on high strength concrete, International Journal of Applied Engineering Research,V-9,I-22,PP-5427-5432,Y-2014.

3. Dayakar P., Vijay Ruthrapathi G., Prakesh J., Management of bio-medical waste, International Journal of Applied Engineering Research,V-9,I-22,PP-5518-5526,Y-2014.

4. Swaminathan N., Dayakar P., Resource optimization in construction project, International Journal of Applied Engineering Research,V-9,I-22,PP-5546-5551,Y-2014.

5. Venkat Raman K., Dayakar P., Raju K.V.B.,An experimental study on effect of cone diameters in penetration test on sandy soil, International Journal of Civil Engineering and Technology,V-8,I-8,PP-1581-1588,Y-2017. 
6. Saritha B., Chockalingam M.P.,Photodradation of malachite green DYE using TIO2/activated carbon composite,International Journal of Civil Engineering and Technology,V-8,I-8,PP-156-163,Y-2017

7. Shendge R.B., Chockalingam M.P., Saritha B., Ambica A.,Swat modelling for sediment yield: A case study of Ujjani reservoir in Maharashtra, India,International Journal of Civil Engineering and Technology,V-9,I-1,PP-245-252,Y-2018

8. Chockalingam M.P., Balamurgan V.,Modernisation of an existing urban road-sector in Chennai, a case study report,International Journal of Civil Engineering and Technology,V-8,I-8,PP-1457-1467,Y-2017

9. Saritha B., Chockalingam M.P.,Adsorption study on removal of basic dye by modified coconut shell adsorbent, International Journal of Civil Engineering and Technology,V-8,I-8,PP-1370-1374,Y-2017

10. Saritha B., Chockalingam M.P.,Adsorptive removal of heavy metal chromium from aqueous medium using modified natural adsorbent,International Journal of Civil Engineering and Technology,V-8,I-8,PP-1382-1387,Y-2017

11. Chockalingam M.P., Palanivelraja S.,Retrospective analysis of a theoretical model used for forecasting future air quality near the north Chennai thermal power plant,International Journal of Civil Engineering and Technology,V-8,I-8,PP-1457-1467,Y-2017

12. Saritha B., Chockalingam M.P.,Photodegradation of methylene blue dye in aqueous medium by $\mathrm{Fe}-\mathrm{AC} / \mathrm{TiO} 2$ Composite,Nature Environment and Pollution Technology,V-17,I-4,PP-1259-1265,Y-2018

13. Shendge R.B., Chockalingam M.P., Kaviya B., Ambica A.,Estimates of potential evapotranspiration rates by three methods in upper Bhima Basin, In Maharashtra, India,International Journal of Civil Engineering and Technology,V-9,I-2,PP-475-480,Y-2018

14. Shendge R.B., Chockalingam M.P.,The soil and water assessment tool for Ujjani Reservoir,International Journal of Mechanical Engineering and Technology,V-9,I-2,PP-354-359,Y-2018

15. Shendge R.B., Chockalingam M.P.,A review on soil and water assessment tool,International Journal of Mechanical Engineering and Technology,V-9,I-2,PP-347-353,Y-2018

16. Sachithanandam P., Meikandaan T.P., Srividya T.,Steel framed multi storey residential building analysis and design,International Journal of Applied Engineering Research,V-9,I-22,PP-5527-5529,Y-2014

17. Meikandaan T.P., Ramachandra Murthy A.,Study of damaged RC beams repaired by bonding of CFRP laminates,International Journal of Civil Engineering and Technology,V-8,I-2,PP-470-486,Y-2017

18. Meikandaan T.P., Ramachandra Murthy A.,Retrofittng of reinforced concrete beams using GFRP overlays,International Journal of Civil Engineering and Technology,V-8,I-2,PP-423-439,Y-2017

19. Meikandaan T.P., Ramachandra Murthy A.,Flexural behaviour of RC beam wrapped with GFRP sheets,International Journal of Civil Engineering and Technology,V-8,I-2,PP-452-469,Y-2017

20. Meikandaan T.P., Murthy A.R.,Experimental study on strengthening of rc beams using glass Fiber,International Journal of Civil Engineering and Technology,V-9,I-11,PP-959-965,Y-2018

21. Meikandaan T.P., Hemapriya M.,Use of glass FRP sheets as external flexural reinforcement in RCC Beam,International Journal of Civil Engineering and Technology,V-8,I-8,PP-1485-1501,Y-2017

22. Saraswathy R., Saritha B.,Planning of integrated satellite township at Thirumazhisai,International Journal of Applied Engineering Research,V-9,I-22,PP-5558-5560,Y-2014

23. Saritha B., Ilayaraja K., Eqyaabal Z.,Geo textiles and geo synthetics for soil reinforcement,International Journal of Applied Engineering Research,V-9,I-22,PP-5533-5536,Y-2014

24. Ambica A., Saritha B., Changring G., Singh N B., Rajen M., Salman Md.,Analysis of groundwater quality in and around Tambaram taluk, Kancheepuram district,International Journal of Civil Engineering and Technology,V-8,I-8,PP-1362-1369,Y-2017

25. Arunya A., Sarayu K., Ramachandra Murthy A., Iyer N.R.,Enhancement of durability properties of bioconcrete incorporated with nano silica,International Journal of Civil Engineering and Technology,V-8,I-8,PP-1388-1394,Y-2017

26. Ilayaraja K., Krishnamurthy R.R., Jayaprakash M., Velmurugan P.M., Muthuraj S.,Characterization of the 26 December 2004 tsunami deposits in Andaman Islands (Bay of Bengal, India),Environmental Earth Sciences,V-66,I-8,PP-2459-2476,Y-2012

27. Ilayaraja K.,Morphometric parameters of micro watershed in Paravanar sub-basin, Cuddalore District,International Journal of Civil Engineering and Technology,V-8,I-8,PP-1444-1449,Y-2017

28. Ilayaraja K., Singh R.K., Rana N., Chauhan R., Sutradhar N.,Site suitability assessment for residential areas in south Chennai region using remote sensing and GIS techniques,International Journal of Civil Engineering and Technology,V-8,I-8,PP-1468-1475,Y-2017

29. Ilayaraja K., Reza W., Kumar V., Paul S., Chowdhary R.,Estimation of land surface temperature of Chennai metropolitan area using Landsat images, International Journal of Civil Engineering and Technology,V-8,I-8,PP-1450-1456,Y-2017

30. Chitra R.,Experimental study on beam using steel fiber and latex,International Journal of Civil Engineering and Technology,V-8,I-8,PP-1395-1403,Y-2017

31. Chitra R.,Analysis of traffic and management at Kovilambakkam intersection,International Journal of Civil Engineering and Technology,V-8,I-8,PP-1433-1443,Y-2017

32. Aswathy M.,Experimental study on light weight foamed concrete,International Journal of Civil Engineering and Technology,V-8,I-8,PP-1404-1412,Y-2017

33. Aswathy M.,Wastewater treatment using constructed wetland with water lettuce (Eichornia Crasipies),International Journal of Civil Engineering and Technology,V-8,I-8,PP-1413-1421,Y-2017

34. Kiruthiga K., Anandh K.S., Gunasekaran K, Assessment of influencing factors on improving effectiveness and productivity of construction engineers, 2015, International Journal of Applied Engineering Research, V - 10,I -17,p -13849-13854.

\section{AUTHORS PROFILE}

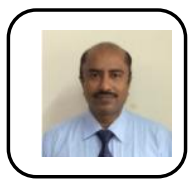

P. Dayakar, Associate Professor, Department Of Civil Engineering,,Bharath Institution Of Higher Education And Research,TamilNadu, India

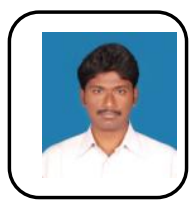

K. Venkat Raman, Student,Department Of Civil Engineering,,Bharath Institution Of Higher Education And Research,TamilNadu, India

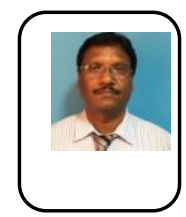

R.Venkatakrishnaiah Associate Professor ,Department Of Civil Engineering,,Bharath Institution Of Higher Education And Research,TamilNadu, India 